\title{
Islamic Identity, Ethical Principles and Human Values
}

\author{
Mansoureh Ebrahimi (PhD) \\ Senior Lecturer at Faculty of Islamic Civilization, Universiti Teknologi Malaysia
}

Kamaruzaman Yusoff (PhD)

Professor at Faculty of Islamic Civilization, Universiti Teknologi Malaysia

\begin{abstract}
Human ethics and values in general and Islamic ethics in particular have been studied as matters of concern since prophet Adam received respect from the angels in form of their prostration and then descended from alJannah (heaven) to earth. In surah al-Isra', verse 70, Allah says, "And We have certainly honored the children of Adam and carried them on the land and sea and provided for them of the good things and preferred them over much of what We have created, with [definite] preference." Hence, human beings were created to do what is good while being granted good things in the world. Islamic ethics address the means whereby mankind ideally accommodates divine guidance as applicable human behavior as well as good conduct and personal morality. This paper investigates the importance, essence and characteristics of Islamic ethics. Although Islamic attributions have significantly contributed to all civilizations, contemporary events raise issues that require a revisit. The authors submit this is because Islam's Code of Ethics is grossly misunderstood, especially concerning the office of God's vicegerent. This comprehensive study uses a qualitative approach and cites various verses of al-Quran and portions of the Prophet's Sunnah to support an analysis that emphasizes Islam's ethical principles and human values. By widely referencing verses from al-Quran, the authors highlight Islamic ethics and life principles that have had significant effects on civilization as valuable precepts for all aspects of daily living.
\end{abstract}

Keywords: Islamic ethics, characteristics of Islamic ethics, human values

\section{Introduction}

The word 'ethics' derives from the Greek word ethos, which means 'character' or 'custom' (Ahmet and Akdogan, 2012). Human action, behavior, spirit, reasoning and culture comprise moral systems established by mankind. Ethics are referred to by several Arabic terms including ma'ruf (approved), khayr (goodness), haqq (truth and right), birr (righteousness), qist (equity), 'adl (equilibrium and justice), and taqwa (pious) (al-Hassan et al. 2013). Taken together they describe attributions that define an advanced human society in which high levels of culture, science, industry and government have been attained (John, 1991).

The Arabic term for ethics is akhlaq. Its singular form, khulq, is mentioned in As-Shu'ara: 137 and al-Qalam, 68:4. Another Arabic word is adab (manner) is closely related to akhlaq. Although some scholars think both terms have the same meaning there are essential differences that indicate application and source (Abdurezak, 2011). Akhlaq, is a characteristic state of soul that determines human actions based on moral philosophy; adab is the actual practice of moral philosophy. Moreover, Akhlaq describes a broad range of activities characterized as Amal Salih or 'virtuous deeds' in al-Quran (Nanji, 1991).

According to al-Ghazali, akhlaq defines the science or study of the human soul in terms of qualities and characteristics that are congruent with methods of behavioral application. Al-Ghazali also stated this science comprised two forms: khalq (the physical) and khulq (or akhlaq), which is the manifestation of actions that are rooted in the soul. Al-Ghazali posited that Islamic ethics teach the soul to behave well, do what is good and guard against vices. From his viewpoint, Islamic ethics concern specific religious beliefs with regard to the actual practice of right vs. wrong behavior and not mere understanding (Al-Ghazali, 2014, P. 461). Accordingly, al-Ghazali's opinion of akhlaq is strongly related to Islamic ethical positions on righteous deeds towards others and towards God through the actually knowing ones' self, and Almighty Allah, and worldly 
realities, and the reality of the Hereafter (Al-Ghazali, 2014, P. 11). Similarly, other philosophers such as al-Farabi, Fakhruddin al-Razi, al-Tusi, al-Dawani, etc., mentioned a direct relation between akhlaq and human actions in which characteristics of the human soul determine individual accomplishments.

Science and technology have developed rapidly bringing numerous benefits and opportunities (Saifuddeen et al. 2013). Ethics play a crucial role in improving qualitative outcomes that advance several sectors such as surgery, agriculture, astronomy, information technology, military capabilities and numerous fitting innovations. Despite ethical contributions to the increasing growth of science and technology, certain areas lack ethical oversight, which has consequently allowed severe challenges and technological risks to the world at large.

According to Latifah et al. ( 2009), most developments in science and technology are pioneered and established by excellent research. However, many participants have disregarded ethical and moral concerns and their efforts have produced unethical outcomes. Nuclear energy and weapons, for example, continue to inflict pain and suffering through atomic radiation (Ahmad, 2016).

For truly progressive benefits, the fields of science and technology require ethical constraints, especially since disastrous results from scientific endeavors cannot be considered ethically neutral. Hence, this review of Islamic Ethics should stimulate fascinating new advances in science and technology with respect to applied Islamic Ethics as a guide to safeguard humanity from destruction due to the decline of morals. Applied Ethics ensure civilization is sustained via important components having to do with education, training and practice (Helmut, 1995). Ethical practices also fundamentally strengthen and protect individual and communal rights within the extremely broad Islamic framework. Muslims also believe we are born with a sound moral nature that responds to faith and ethical values (Nikhat, 2014).

Regarding the practice of blameless ethical behavior in all circumstances, Islam teaches that a strong relation with God leads to virtuous conduct. Human beings should convey piety and righteousness in life with sincere faith towards others made manifest by good habits that are well defined. Such a predisposition builds civilization by optimizing life ways that successfully benefit society. There is no doubt that Islamic ethics contributed to civilization from the beginning. Presently however, ethical values are neglected and consequently places civilization in danger. Al-Hassan et al. (2013) holds forth that several ethical theories, especially Islamic perspectives, need developing to clarify right vs. wrong activities for the purpose of distinctly preventing unethical matters from arising. This paper thus highlights the contribution of Islamic ethics towards building civilization and the challenges that confront the practice of these ethics in today's world.

\section{The Significance of Islamic Ethics}

Ethics are important for the development of beneficial Muslim conduct and character as commanded by Allah in al-Quran.

"God enjoins justice (and right judgment in all matters), and devotion to doing good, and generosity towards relatives; and He forbids you indecency, wickedness, and vile conduct (all offenses against Religion, life, personal property, chastity, and health of mind and body). He exhorts you (repeatedly) so that you may reflect and be mindful!" (An-Nahl, 16:90)

Islamic ethics define value as 'good character' shaped by al-Quran's teachings and Prophet Muhammad's Sunnah as well as numerous precedents set by Islamic jurists (Sharia and Fiqh). Thus, Islam presents a complete code for living that is framed by ethical values. Islam's guidelines for individuals, family, society, political, economics, judiciary and all aspects of modern living are replete with moral instructions. In al-Quran, many terms describe the concept of ethics such as khayr (goodness), maslahat (public interest), birr (righteousness), qist (equity), 'adl (equilibrium and justice), haqq (truth and right), ma'ruf (known, approved), nahi munkar (avoidance of bad and harmful things), and Taqwa (piety). Moreover, above them all al-Quran commands Muslims to not only do good and but also to forbid evil actions (Zaroug, 1999).

As a fundamental requirement for beneficial living, ethics provide the means for deciding purposeful courses of action that otherwise would become random, arbitrary and even aimless (Adibah, 2013). In a social environment that lacks an ethical code of conduct, there is no way to judiciously obtain specific outcomes because there are no established methods to choose, theoretically, from among unlimited objectives. Even within standard ethical milieus one could be successfully prevented from pursuing individual goals. Based on rational ethical standards, humans can more correctly organize and thus prioritize goals and actions to optimize outcomes. Any flaw in requisite ethics also reduces one's ability to pursue certain endeavors successfully. Thus, morality and integrity are important characteristics that demonstrate a nation's integrity, even for those with no aspirations for a career in law enforcement. We instinctively know that it is good and moral 
to act with integrity, but by establishing mutual understanding for the dignity and necessity of providing moral reasoning we become motivated to champion such behavior (Lafollette, 2007).

Regardless of one's position in society, the main reason to lead a moral life of integrity is to construct a better society by treating every member equally according to a uniform code of principles. Other reasons are to secure meaningful employment, business success and reduce levels of communal and personal anxiety. Ultimately, the importance of ethics do not concern philosophical understanding but rather the improvement of how we live (Lafollette, 2007). Being moral enriches our lives and the lives of those around us. It is especially important to live a moral life when young, as it is helpful to exercise and practice ethical concepts before being confronted by more complex issues. Ethics, like most everything else we strive to be good at, requires practice and effort to perfect correct decision making throughout life and pays great dividends when one is faced with serious moral dilemmas (Lafollette, 2007).

Islamic ethics also emphasize the need to understand and develop virtue. Knowing that we ought to behave in a certain way but missing an opportunity to exercise moral behavior indicates the need to "sharpen moral vision". For example, we know that we ought to stay in good physical shape but most of us do not. This illustrates a need to be mindful of an important virtue (in this case, perseverance) that should be developed.

Muslims also believe that science and technology must follow a process of evidence, justification and truth.

"They (Jews or Christians) say that none will enter Paradise unless he be a Jew or a Christian. That is their wistfulness (vain desires and fancies). Say: 'Produce your proof if you are truthful'." (Al-Baqarah, 2:111)

\section{Sources of Islamic Ethics}

As a set of beliefs and directives for action without limitations of time, space and convention, Islamic ethics initially begin with al-Quran, the revelation God's word, which is full of beautiful expressions and wisdom; and secondly from the Sunnah's attributions ascribed to the last messenger of Allah that characterize his ethical practices. Both al-Quran and Sunnah attach great importance to a code of ethics that fundamentally aims to form honest personalities with truly human identities (Kemal, 2010). Prophet Muhammad was sent to preach an essentially moral message as specifically expressed in al-Quran:

"We have not sent you (O Muhammad) but as an unequalled mercy for all worlds." (Al-Anbiya', 21:107)

For this reason, the best sources of Islamic ethics provide ethical concepts that are not only taught in al-Quran but were also embodied by the Prophet's example; thus providing us with the best model to emulate. Al-Quran states that the best person is a person who upholds moral foundations and invites others to practice these values (Abdurezak, 2011).

"Who is better in speech than one who calls (men) to Allah, works righteousness, and says, I am of those who bow in Islam?" (Al-Quran 41:33)

Moreover, the exemplary moral life of Prophet Muhammad articulated various applications of Islamic morality and ethics. Hence, ethics, from the Islamic perspective, signify behavioral traits that are regarded as good that are based on al-Quran and Sunnah. Both sources are referenced for laws and principles that guide the Islamic way of life as mentioned in the following verse:

"... We have sent down on you the Book as an exposition of everything (that pertains to guidance and error, and to the knowledge of good and evil, and to happiness and misery in both worlds), and guidance and mercy and glad tidings for the Muslims (those who have submitted themselves wholly to God)." (An-Nahl, 16:89)

Thus, Islamic ethics not only define ethical behavior but also instruct us in the building of a better way of life for the individual and social order in which he/she dwells. Islam instructs us that Allah created mankind and provided laws and regulations concerning belief and moral instructions suited for mankind's implementation and governance. The modern age confronts us with many challenges including accelerating developments in science and technology. As Islam is a complete dynamic and holistic religion, everything that happens can definitely be handled by Islamic ethics with proper guidance from alQuran and Sunnah and other Islamic sources. Islamic ethics teach us how to conduct ourselves in a goodly manner and avoid wrong doing (Brown, 1999). Thus, Islamic ethics offer optimized guidelines to govern modern science and technology with assure beneficial outcomes for everybody. 
In addition, Islamic law depends on two further sources, ljma' and Qiyas (Huda, 2016). ljma' is a consensus of opinion offered by ulema' or scholars within a community in the absence of a specific legal ruling for a certain situation. Qiyas occurs when people attempt to obtain a legal ruling that, unfortunately, has not been clearly addressed in other sources. Therefore, judges may use analogy, reasoning and legal precedent to decide new case law (Huda, 2016).

In al-Quran, God revealed the eternal message of Islam as guidance for personal life as well as social life. The Sunnah completes these guiding principles with the Prophet's example, interpretation and explication so that Islamic law is practiced with required precedent (Sikandar, 2005). In Islam, law and morality cannot be separated as both are intermixed and righteous deeds are established out of necessity once the religion is firmly believed. Islam is a perfect combination of faith (iman) and practice (amal) in which both elements represent law and morality, as mentioned in Shariah law and ordained by God. Literally al-Quran mentions that Muslims must take care of mental attitude by not cheating or exploiting the trust of others and by avoiding injustice and the distortion of rights as well as disloyalty.

"If any person is so false, He shall, on the Day of Judgment, restore what he misappropriated; then shall every soul receive its due, - whatever it earned, - and none shall be dealt with unjustly." (Al-Quran 3:161)

Another verse promotes the practice of good moral behavior by expressing kindness, generosity, self-discipline and constantly forgiving the mistakes of others.

"Those who spend (freely), whether in prosperity, or in adversity; who restrain anger, and pardon (all) men; -for Allah loves those who are virtuous, through such actions, that is to say, He will reward them." (Al-Quran 3:134)

\section{Human Characteristics of Islamic Ethics}

Undoubtedly, Islamic ethics improve human relations and shield civilizational constructs with metaphysical ramparts of decency and order. The several characteristics of Islamic ethics are exemplified in the message of al-Quran as revealed to Prophet Muhammad and as inscribed in his Sunnah (Nanji, 1991).

Islamic ethics apply to various aspects of life including governance, business and the management of personal matters. Prophet Muhammad, who possessed perfect ethics, once said, "I was sent to perfect good morals" (Al-Sahihah, 2010). His mission was to imprint human hearts with impeccable morals that would guide us with exemplary conduct towards each other. Major characteristics of Islamic ethics include bravery, consideration, experience, fairness, justice, honesty and the pursuit of knowledge. Each ethic is discussed in detail below, along with examples and reference to al-Quran and Sunnah.

\subsection{Bravery}

Courage is required for those working in the realms of Science and Technology. A courageous soul will survive the incredibly wild growth of science and technology (Rawls, 1999) and subsequent influences on the development of modern Muslims life ways. Scientific activity requires much effort and risk taking, including failures and even harm when one is striving to achieve desirable outcomes. Hence, a brave, courageous attitude helps scientists overcome confrontations with numerous challenges.

The brave character is mentioned numerous times in al-Quran with respect to protecting Muslim property. Muhammad set an excellent example of noble manners and merits, including courage. Al-Quran presents the Prophet as the best of moral role models: "You are surely of a sublime character, and do act by a sublime pattern of conduct" (Al-Qalam, 68:4). His valor was a byword among his contemporaries because he gallantly stood against the greatest odds while enduring painful injuries and still victoriously fought on to overcome and afterwards show mercy to stone-hearted ignorant Arabian infidels (Emara, 2011). He endured pain and sufferings for thirteen long years in Mecca while inviting people to Islam, without ever being intimidated by the sheer force, numbers or arrogance of the Jahiliyya. The Prophet never succumbed to fear or threats in extremely difficult situations and crises. He put his full trust in Allah and depended on Him alone (Syed, 2010). He accepted the decrees of his Lord, was satisfied with God's support, and trusted God's promise.

Such bravery also applies to those working in science and technology who should be courageous enough to stand up and protect knowledge from unethical applications (Pollock, 2007). When conducting scientific activities, the scientist should always have faith and rely only on Allah, Who said: 
"Do not fear! Surely I am with you, hearing and seeing" (Taha, 20:46); and "As for those who believe and do good, righteous deeds, and have humbled themselves before their Lord, they are the companions of Paradise; they will abide there-in." (Hud, 11:23)

\subsection{Consideration}

The way of life set forth in al-Quran and authentic Sunnah is not limited to creed, worship or the actions of our limbs or our slave-relationship with our Creator. It goes further to command us to be well-mannered with Allah's creation: to be kind and charitable to all creatures and to maintain good relationships with them (Sandel, 2010). Hence, Islam charges us to be friendly and to treat others well while considering their feelings and emotions according to sublime Islamic rules and guidelines. This concerns manners, morals and social relations between individuals as to duties and rights. It also commands us to choose appropriate words according to different situations. Allah says in al-Quran:

"... And do good to parents in the best way possible, and to the near (relatives), to orphans and to the destitute; and speak kindly and well to the people; and establish prescribed prayer in conformity with its conditions; and pay the prescribed purifying alms (the Zakah)..." (Al-Baqarah, 2:83)

Consideration of beneficial effects on humans, animals and environment help us attain success in science and technology and can be deemed a necessary ethic, as al-Quran commands us to perform what is good towards animals and environment. This also applies to the acceptance of opinions offered by others and the sharing of thoughts and knowledge (Al-Munajij, 2015).

"(Should not those whose ears are closed to the Quran look around themselves to see the signs of the truth?) No living creature is there moving on the earth, no bird flying on its two wings, but they are communities like you..." (Al-An'am, 6:38)

"O you, who have believed! Avoid much suspicion, for some suspicion is a grave sin (liable to God's punishment); and do not spy (on one another), nor backbite (against one another). Would any of you love to eat the flesh of his dead brother? You would abhor it! Keep from disobedience to God in reverence for Him and piety. Surely God is One Who has truly returned repentance with liberal forgiveness and additional rewards, All-Compassionate (particularly towards His believing servants)." (Al-Hujurat, 49:12)

The creation of scientific and technological knowledge receives positive or negative feedback from community and colleagues. The Islamic ethical code of conduct recommends that all who play major roles in such venues conduct wellmannered approaches to the opinions and thoughts of others. As mentioned in the above verse, negative assumptions (suspicions) are warned against by Allah and should be avoided by Muslims.

\subsection{Experience}

Al-Ghazali stated that experience contributes to knowledge in addition to reason and transmission from reliable sources. Informing others about one's experiences and knowledge plays a significant role in Islam's system of responsible ethics. For example, the prophet always deferred to the community when seeking to solve problems related to differences of opinion about aqidah (faith) and akhlaq because his role was to help the community in a good way, as commanded by Allah in Al-Quran:

"(Thus did We command you): Judge between them with what God has sent down, and do not follow their lusts and fancies, and beware of them, lest they tempt you away from any part of what God has sent down to you. If they turn away, then know that God wills only to afflict them for some of their sins. And many among human beings are indeed transgressors." (Al-Maidah, 5: 49)

Furthermore, expert experience is very useful, mostly when planning, developing, controlling and maintaining each community, and especially when upgrading effective decision making for future projects. Collaboration between experienced designers is purposed to produce brilliant ideas and applications for organizations when assisting subordinate knowledge transfer.

\subsection{Fairness/Justice}

As a high moral principle and from Islam's ethical perspective, justice is defined as treating others fairly by providing them with what they rightfully deserve in the Islamic context, and also by rightfully positioning things. God said in al-Quran: 
"God commands you to deliver trusts (including public and professional duties of services) to those entitled to them, and when you judge between people, to judge with justice. How excellent is what God exhorts you to do. Surely God is AllHearing, All-Seeing." (An-Nisa', 4:58)

Justice is held in the highest moral regard among Muslims as a means to strengthen their defense against enemies. Even at war, Muslims are required to firmly administer justice. Islam also requires just settlement of arguments between married couples. For justice to be fully applied to the highest degree, Muslims must purify themselves by keeping their acts and beliefs virtuous. They should also stand tall and proudly protect the sanctity of Islam by becoming those who deliverer justice.

"O you who believe! Be upholders and standard-bearers of right for God's sake, being witnesses for (the establishment of) absolute justice. And by no means let your detestation for a people (or their detestation for you) move you to (commit the sin of) deviating from justice. Be just: this is nearer and more suited to righteousness and piety. Seek righteousness and piety, and always act with reverence for God. Surely God is fully aware of all that you do." (Al-Maedah, 5:8)

This verse shows that God disallows injustice and hatred (e.g., through discrimination) and that $\mathrm{He}$ also disregards color and ethnic differences because people are equal in His eyes. Hence, God commands humankind to hold justice with the highest esteem. Allah has repeatedly reprimanded mankind with regard to injustice in al-Quran, wishing to protect us from the mistakes of our ancestors. The command from Allah requires Muslims to refrain from injustice and thus avoid the wrath that has fallen on Jews and Christians due to disobedience. He also warns against acts of treachery:

"If you have strong reason to fear treachery from a people (with whom you have a treaty), return it to them (i.e. publicly declare to them, before embarking on any action against them, that you have dissolved the treaty) so that both parties should be informed of its termination. Surely God does not love the treacherous." (Al-Anfal, 8:58)

\subsection{Honesty}

Honesty is held in high regard. The Prophet even said to 'wait for the Day of Judgment when honesty is mislaid'. This indicates the woeful end of time and Judgment Day, when people will be condemned and punished because of dishonest misconduct. Hence, in Islam, honest conduct is expected when dealing with other people and serves to unite notions of candor and truthfulness in actions, relationships and verbal exchanges. Thus, Islam compels truthfulness and forbids deceit. Al-Quran commands honesty.

"O you who believe! Keep from disobedience to God in reverence for Him and piety, and keep the company of the truthful (those who are also faithful to their covenant with God)." (At-Tawbah, 9:119)

Prophet Muhammad, as a firm believer in Allah, is the perfect example of a character that embodied honesty and received the titles, al-Amin, the trustworthy, and as sadiq, the truthful, even prior to his elevation to Prophethood.

"Those who have believed in God and His Messengers (those whose actions prove their profession of faith) - they are, in the sight of their Lord, the loyal and truthful (to God in whatever they do and say), and the witnesses (who have borne testimony to the truth with their lives). They have their (particular) reward and their (particular) light. But those who disbelieve and deny Our manifest signs and Revelations - they will be the companions of the Blazing Flame." (Al-Hadid, $57: 19)$

Allah strictly forbids deceit and said that hellfire awaits those who conduct their life dishonestly. Allah also commands Muslims to be honest when consuming wealth.

"O you who believe! Do not consume one another's wealth in wrongful ways (such as theft, extortion, bribery, usury, and gambling), except it be dealing by mutual agreement; and do not destroy yourselves (individually or collectively, by following wrongful ways like extreme asceticism and idleness. Be ever mindful that) God has surely been All-Compassionate towards you (particularly as believers)." (An-Nisa', 4:29)

Allah forbids the consumption of other people's wealth with dishonest intent and reprimands Muslims on the matter to prevent murder as a consequence. 
"Do not confound the truth by mixing it with falsehood, and do not conceal the truth while you know (the meaning and outcome of what you do, and that what you strive to hide is true, and that Muhammad is the Messenger of God, whose coming you have been anticipating)." (Al-Baqarah, 2:42)

It is antithetical to Islamic ethics to mix truth with falsehood. An instance of this is telling partial truth when witnessing a crime committed by someone related to you. Allah forbids the concealing of truth when you know it, for example, lying for a family member who committed theft to prevent the pursuit of justice. Time and again, Allah reprimands Muslims to follow his instructions via Al-Quran to prohibit lying.

\subsection{On Being Knowledgeable}

Being knowledgeable is essential for a successful society. Knowledge is gained via informal and formal study and is a major Islamic contribution to human development (Al-Rawahy, 2013). Generally, knowledge derives from individuals who have beliefs and values that promote the creation of knowledge for competitive advantages (Sokhanvar et al. 2014). Islamic concepts of knowledge include transcendent aspects as well as sensory perceptions (Faruqi, 2007). Hence, a Muslim must obtain knowledge to understand God and enter into scientific activities that benefit human welfare by utilizing universal resources (Faruqi, 2007). Al-Quran, Islam's holy book, contains detailed knowledge and its contents are securely protected and guaranteed by Almighty Allah.

"Assuredly We have brought them a Book (the meaning and commandments of) which We set out in detail with knowledge, as guidance and mercy for people who will believe and who will deepen in faith." (Al-A'raf, 7: 52)

"Indeed, it is We, We who sent down the Reminder in parts, and it is indeed We Who are its Guardian." (Al-Hijr, 15: 9)

As science and technology develop to fulfill human needs, products produced by knowledgeable people will certainly be accepted. Knowledge varies from one person to another because judgments based on individual thought processes cannot be transferred genetically (Sokhanvar et al., 2014). Al-Quran even affirms this difference.

"Is he who worships God devoutly in the watches of the night prostrating and standing, who fears the Hereafter and hopes for the mercy of his Lord (to be likened to that other)? Say: "Are they ever equal, those who know and those who do not know?" Only the people of discernment will reflect (on the distinction between knowledge and ignorance, and obedience to God and disobedience), and be mindful." (Az-Zumar, 39: 9)

In the pursuit of knowledgeable advances, a strong relationship exists between knowledge and emotion (Antlova et al. 2015), one that highlights the importance of morals, values, ethics and their benefits to society (Chowdhury, 2016). This is because knowledge is used in decision making (Tennoy et al. 2015) and plays a more important role than does desire (Antlova et al. 2015). For example, drugs commonly used for medical purposes can also be misused solely for the purpose of profit making. Moreover, such drug abuse causes much harm to those who are addicted. This is unethical and demonstrates that knowledge is insufficient when emotions (desires) are not controlled and a person's credibility can easily fall into disrepute. This statement relates to a verse in al-Quran:

"No, indeed! Those who do (the greatest) wrong (by associating partners with God) follow only their lusts and fancies, without (basing on any) knowledge. Who has the power to guide him whom God has led astray (on account of following merely his lusts and fancies)? And such have none to help them (to salvation)." (Ar-Rum, 30:29)

Islam teaches us to live and consume responsibly without causing negative effects to any living or non-living thing (AlRawahy, 2013). With appropriate use of knowledge with regard to science and technology, immoral issues cannot arise when people realize their responsibilities to cause and reap what is beneficial for all. Moreover, knowledgeable upgrades in science and technology continue to improve human life without neglecting ethics.

To usher characteristics of Islamic ethics into an individual's life it becomes everyone's responsibility to reject unethical behavior. Thus, we are required to react appropriately and in a good manner to encourage ethical behavior as mentioned in al-Quran, most especially because Almighty Allah does not change people until they change themselves.

"(Every person advances through varying states before and after, and) by God's command attendant angels succeeding one another accompany him before and after him to guard him (and record his deeds). God does not change what is in 
themselves. When God wills evil for a person (in consequence of their own evil deeds), it cannot be averted, and apart from Him, they have no protector." (Ar-Rad, 13: 11)

\section{Essential Islamic Values and Ethics for the Development of Civilization}

Islam teaches that human beings were created as God's khalifah (vicegerent) to realize amanah (His will). To enable man for the task of building civilization, Allah revealed Shari'ah law, which sets forth rules to govern various aspects of Islam. This includes ideology and laws that are essential for the development of civic-minded citizens and a constructive social order. Its accompanying codes of ethical behavior are basic guidelines for the development of upright and wholesomely integrated individuals and societies (Sikandar, 2005). Hence, as khalifah, men are required to ensure that life is improved by civilizing their communities.

Men also have an inherent need to perform ethical duties and constantly upgrade their quality of life. For this reason, human conduct is considered ethical when it contributes to civilizing efforts in line with Allah's will, which then qualifies such communities as guided by an Islamic ethical system that is replete with divine, transcendent and universal principles. As stated earlier, Islamic ethics offer a complete guide for the applicable management of akhlaq and adab to build a strong civilization. The Islamic ethical system considers the role of spiritual motivation in the determination of a man's attitude as either good or bad. Optimally, ethics, religion and law are complementary and lack contradiction, and thus constitute moral practice.

Defined as the 'process of civilizing to advance and develop human societies', civilization includes advanced achievements that portray a systematic and progressive system. A civilized society demonstrates various characteristics that exemplify formative fundamentals of a complete and forward-thinking societal system. Islam's contribution to civilization and social development is established as a 'glorious' influence on western civilization, including the growth of knowledge, which was made possible by contacts with Muslims (O'Brien, 1999). According to Syed Othman Alhabshi and Nik Mustapha Nik Hassan (1997):

"Since its first appearance on the world scene, Islam has played its part in the development of civilization, first by transforming an Arab Jahili society into a tawhidi one; second by influencing neighboring societies through international and intercultural contact; and third by acting as a catalyst for the transmission of certain values from one society to another ... the biggest empire in world history was built by Muslims through their missionary activities, military might and efficient and just administrative rule."

Islamic civilization can be defined by the spiritual and material achievements of Muslims both. Urban areas are centers of Islamic civilization where one observes magnificent architecture as well as advances in science and technology accompanied by spiritually guided laws that uphold the economy as well as family relationships, education and political relations. All is based on steadfast moral platforms provided by shari'ah and iman (belief), as found in al-Quran and Sunnah. It became obvious during the medieval period that many Muslims intellectuals were leaders in administration, astronomy, economic development, agriculture, industry, engineering, defense, science, mathematics, shipping, navigation, medicine and other fields of art and science.

Their outstanding achievements and contributions to civilization established significant milestones. Therefore, we cannot be remiss when discussing the influence of Islamic ethics on the building of civilization because ethics guided relationships and achievements obtained with a view towards Islamic principles that materially realized a great civilization.

Islamic political philosophy places an essential need on the election of good leaders within a social system focused on family centered communities, states, organizations, etc., all framed by the context of morally imbued Islamic ethics. A famous narrated hadith of the Prophet reports "For a long journey with more than three musafir (travelers) one should be elected as amir (leader)'. Islam also places much emphasis on the concept of shurah (consultation). A full chapter in alQuran, Ash-Shura, praises consultation.

"Those who hearken to their Lord, and establish regular prayer; who (conduct) their affairs by mutual consultation; who spend out of what We bestow on them for Sustenance are praised" (Al-Quran, 42:38).

Moreover, previous Muslim civilizations constantly improved their economies and positions in the world by vigorously pursuing industrialization (Ghazali, 1996). Moral values are one of the most important components that contributing towards economic progress. Therefore, good moral values in the pursuit of economic development require ethical adherence. In 
this regard, we refer to al-Quran and Sunnah to appreciate the emphasis placed on the proper use of the intellect and the need for wise reflection on the bounties of Allah and their proper utilization (Ghazali, 1996).

Discussion of socio-cultural development is fundamentally about ethics, which are most essential in the formation of all civilizations. The three main objectives of Islamic civilization are to establish the following:

Relationship of man with Allah S.W.T;

Relationship of man with man;

Relationship of man with his environment.

These are possible through 'knowing one's own self', 'knowing the Almighty Allah', 'knowing the reality of the world', and 'knowing the reality of the Hereafter' (Al-Ghazali, 2014).

Man's relation with Allah is paramount as the basic pillar of Islam and the building of a civilized nation. The bedrock of Islamic civilization is iman (faith). However, Islamic civilization was/is not the result of ritual pursuit or even of obedience to Allah but was rather of analyzing and applying injunctions and guidance from Allah as a practicable way of life (Alhabshi et al. 1997). Islam provides guidance for everything concerning daily life ways that positively contribute to society and help develop the state via ethical principles for work, family and neighbors to improve life by making everyone aware of their responsibilities and rights.

In fact, Kïmiyā-i-Sa'ādat is included four essential elements of Islam to obtain alchemy of eternal bliss:

'Ibādat (the acts of worship),

Mu'āmilāt (the dealings),

Muhlikāt (all bad morals such as arrogance, pride, self-appreciation, anger etc.),

Munjīyyāt (all good morals such as love, hope, gratitude, patience) (Al-Ghazali, 2014).

\section{God's Vicegerent: Modernization and Ethical Challenges}

Changes arise in human lifestyles from the development of technology and science that often challenge moral values and cultural mind-sets. Technology and information have also managed to eliminate some limitations of national frontiers. In fact, they allow influences that change perceptions, ideology and various external elements to enter a country without restrictions or controls. Naisbitt (1982) predicted that one out of ten human tendencies in the early 21 st century would be based on information from a globalized world as decisive drivers into the future because information would spread internationally through social network media. Although such powerful influences on civilizational exist, potential adverse effects should not be ignored because they can become a cancer that worsens existing social ills. Islam offers moral perspectives that can counter negative influences by generating authentic harmony and prosperity in a modern world filled with ethical crises.

Undoubtedly modernization allowed rapid urbanization, industrialization and migration from rural areas with some positive impacts but not without rising social ills. A moral crisis occurs when some people are so driven by profiteering that they neglect moral sensitivities. Money oriented incentives have stimulated unethical behavior in all fields of invention and development without any concern or hesitation over adverse affects on environment or community. Without realizing it, problems arise when we stray from man's true purpose in accord with Islamic principles, morals and ethics.

Rapid growth of information technology allows all levels of society to access knowledge and data without restrictions. This also leads to challenging ethical issues that include the validity and correctness of information. Accuracy and authentic truth are important to prevent irregularities and falsehoods from being presented as facts, especially in matters of religious knowledge. Unscrupulous people always find ways to deviate and lie for the expressed purpose of misleading others. A most strikingly misunderstood issue is jihad, which has been wrongly portrayed by and to Muslims as well as non-Muslims. Misinformation is spread by people who fail to comprehend the spiritual significance of jihad and also by those who purposely indulge incorrect interpretations. 
Solely citing Internet sources without confirmation of content validity often causes problems and can even threaten public security. Advances in information technology can also have adverse impacts from intrusions caused by hackers in countries where confidential information is easily compromised. The latest technology also allows for the modification of images that give negative impressions and affect the dignity and position of an individual and his family leading to charges of libel and other more dangerous forms of fitnah. In Islam, the spreading of fitnah is considered a great crime according to al-Quran:

$$
\text { "... and fitnah is more dangerous than killing..." (Al-Quran, 2:191) }
$$

Nowadays, social media networks and personal webpages can share information privately and publicly that has direct impact on social issues. Without restraints, on the surface this can be helpful but many times terrible results can arise that invite the loss of respect for moral values. Hence, development must be oriented towards optimizing human dignity in all realms. Moral considerations are inseparable from spiritual, material, economic and social pursuits. The holistic approach to development offered by Islamic ethics is morally oriented and comprehensively covers multi-dimensional aspects of material and social progress.

The role of knowledge is also important in the formation of personal character. Educational systems should serve as agents of tazkiyah (purification) to produce morally imbued citizens. Knowledge managers should not only recognize matters of good or bad behavior but also implement programs that familiarize students with the constant practice of what is truly beneficial in daily life. According to A. Rahim's (2013) study on Ibn Miskawayh's ethical philosophy, the practice of virtue transforms irrational students to rational individuals who will keep performing good deeds. For Muslims, being rational does not mean only to justify things intellectually but also to examine every single aspect of moral conduct to determine whether such behavior aligns with Islamic law.

In addition, there is a great need for the Muslim Ummah to provide the best example of behavior according to Islam's code of ethics. Thus, Muslims should mirror good manners as indicated by al-Quran, which has called them the best ummah, one that behaves according to what is right and wrong:

"You are the best community that has been raised up for mankind. You enjoin right conduct and forbid wrong" (al-Quran, 3:10).

Regardless of time or place, Islamic ethics provide courses of action that emphasize what should be learned by human beings throughout history. What was considered morally good in the past remains so throughout time. Good individuals will produce a good society. Thus, there is need to apply the deepest wisdom of Islam to contemporary problems in the modern world, especially when dealing with ethical matters.

\section{Conclusion}

Ethics comprise the most important of prerequisite elements for the building of humankind's character and as mentioned in al-Quran: to worship God, to perform what is good and to avoid bad actions. According to al-Quran and Sunnah, Islamic ethics are the most beneficial guidance for use in the advancement of life and the avoidance of wrongdoing. Moreover, they provide motivation for humankind to advance the importance of Islamic ethics in global development. With all the excitement of modern progress, we should not neglect the important role of ethics in the establishment of harmony, prosperity and peace. As the religion of mercy, Islam should be the major reference and guideline in the drafting of a global code of ethics in accord with the characteristics of Islam that brings a complete multidimensional perspective and way of life. In addition, Islam's ethical value judgments transcend worldly gains and relativist interpretations. Thus, we urge the Muslim Ummah to practice true Islamic ethics and to return al-Quran to the mainstream in our approach to problems faced by society today and in the future.

\section{Acknowledgement}

The authors would like to thank the MOE and University Technology of Malaysia (UTM), Research Management Centre (RMC), for $16 \mathrm{H} 48$ grant that have been supported this research.

\section{References}

[1] Abdurezak A. Hashi (2011). Islamic ethics: An Outline of its Principles and Scope., 1(3): 122-130.

[2] Adibah, A. R. (2013). Understanding Islamic Ethics and Its Significance on Character Building. International Journal of Social Science and Humanity, 3(6): 508-513. 
[3] Al-Ghazali, Imam Mohammad (2014). Kīmiyā-i-Sa‘ādat. Effort by Parvin Ghaemi. 6th Edition, Tehran: Nashr-e Peiman.

[4] Al-Hassan, A. A., Faridahwati M. S. and Kamil M. I. (2013). Ethics and Ethical Theories from an Islamic Perspectives. International Journal of Islamic Thought, Vol. 4, Dec.

[5] Ahmad, I. P. (2016). Evaluating Modern Scientific Methodology with Islamic Worldview: Humanizing Science Through Engaging Islamic Ethics. Journal of Education and Social Sciences, 4: 128-132.

[6] Ahmet, N. and Akdogan, C. (2012). Trust (Al-Amanah): A Comparative Study of its Application in Islamic and Western Science. Paper presented at the Asian Conference Ethics, Religion Philosophy.

[7] Alhabshi, S. O. and Nik Hassan (1997). Islamic Civilization: Present and Future Challenges. IKIM (Institute of Islamic Understanding Malaysia).

[8] Al-Munajiji, S. M. S. (2015). Being Considerate of Others' Feelings

[9] Al-Rawahy, K. H. (2013). Engineering Education and Sustainable Development: The Missing Link. ProcediaSoc. Behav. Sci., 102: 392-401.

[10] Al-Sahihah, A.-S. (2010). Narrated by Al-Hakim on the authority of Abu-Hurayrah: Chapter of the history of ancient prophets and messengers, and chapter of signs of Allah's Messenger, namely the signs of prophecy (4221). He said: correct on the condition of Muslim, but they did not narrate it. Both Al-Zahabi and Al-Bayhaqi (in Al-Sunan Al-Kubra, 20571) agreed with him. Al-Albani said: correct. .

[11] Antlova, A., Chudy, S., Buchtova, T. and Kucerova, L. (2015). The Importance of Values in the Constructivist Theory of Knowledge. Procedia-Soc. Behav. Sci., 203: 210-216.

[12] Brown, D. (1999). Islamic Ethics in Comparative Perspective. The Muslim World, LXXXIX(2): 181-192.

[13] Chowdhury, M. (2016). Emphasizing Morals, Values, Ehtics, and Character Education in Science Education and Science Teaching. 4(2): 1-16.

[14] Emara, O. (2011). Muhammad (Peace Be upon Him), the Prophet of Mercy. The Global Program of Introducing the Prophet of Mercy.

[15] Faruqi, Y. M. (2007). Islamic View of Nature and Values: Could These be the Answer to Building Bridges Between Modern Science and Islamic Science. Int. Educ. J., 8(2): 461-469.

[16] Ghazali, A. (1996). A Study of Industrialization: From the Qur'an, The Sunnah and The Islamic Civilization. Institut Perkembangan Minda (INMIND).

[17] Helmut Burkhadt (1995). Priorities for a Sustainable Civilization. IEEE Proceedings, Foundations and Applications of General Science Theory.

[18] Huda (2016). Sources of Islamic Law. The Law and Balance Articles; Religion, Jan.

[19] John David Garcia (1991). Civilization and Ethics Articles. Online, Tribute to Garcia.

[20] Kemal Sandikci (2010). The Sunna as the Basis of Islamic Ethical Thinking. Article on the Last Prophet, March.

[21] Lafollette, H. (2007). The Practice of Ethics. Malden (Ed.)

[22] Latifah, A., Siti Fairuz, S., Abdul Latif, S., Mohamad Sabri, H. and Mohd Nasran (2009). Islamic Ethics in Governing Modern Biotechnology in Malaysia. Paper presented at the 8th WSEAS International Conference on Education and Educational Technology.

[23] Naisbitt, J. (1982). Ten New Directions Transforming Our Lives. Warner Books.

[24] Nikhat Sattar (2014). "Ethics in Islam", Dawn News, 23 May.

[25] Nanji, A. (1991). Islamic Ethics. In P. Singer (Ed.), A Companion to Ethics (pp. 106-118). Oxford: Blackwell Publishing.

[26] Pollock, J. (2007). Ethical Dilemmas and Decision in Criminal Justice

[27] Rahim, A. A. (2013). Understanding Islamic Ethics and Its Significance on Character Building. Int. J. of Soc. Sci. and Humanity. 3(6): 508-513.

[28] Rawls, J. (1999). A Theory of Justice

[29] Saifuddeen, S. M., Wei, C. L., Ibrahim, A. H. and Mhd Khotib, N. A. (2013). Islamic Ethical Framework to Tackle Scientific and Technological Dilemmas. Journal of Dharma, 34(4): 373-386.

[30] Sandel, M. (2010). Justice: What is the Right Thing to Do? Paper, Farrar, Straus and Giroux, New York.

[31] Sayed, Sikandar Shah Haneef (2005). Ethics and Fiqh for Daily Life (1st Edition). IIUM Research Centre, KL, Malaysia.

[32] Sokhanvar, S., Matthews, J. and Yarlagadda, P. (2014). Importance of Knowledge Management Processes in a Project-Based Organization: A Case Study of Research Enterprise. Procedia Eng., 97: 1825-1830. 
[33] Syed, A. (2010). Prophet Muhammad (pbuh): A Mercy to All Creation! (pp. 1-31).

[34] Tennoy, A., Hansson, L., Lissandrello, E. and Næss, P. (2015). How Planners' Use and Non-Use of Expert Knowledge Affect the Goal Achievement Potential of Plans: Experiences from Strategic Land-Use and Transport Planning Processes in Three Scandinavian Cities. Prog. Plan., 109(1).

[35] Zaroug, A. H. (1999). Ethics from an Islamic Perspective: Basic Issues. The American Journal of Social Sciences, 16(3): 45-63. 